\title{
The Short Forms and Long Forms of Proteus
}

\author{
By H. E. JONES* AND R. W. A. PARK \\ Microbiology Department, University of Reading
}

(Accepted for publication 12 January 1967)

\begin{abstract}
SUMMARY
Swarming long forms of Proteus arose from short forms at the edge of a colony on nutrient agar. Specialized small pre-swarmer forms were not seen. The long forms contained many nuclear units and did not have cross walls while actively swarming. Long forms were not found in liquid media. Chemical analysis of short and long forms showed that cell walls of the two forms had qualitatively the same amino acid composition and that inhibition of DNA synthesis was not responsible for the formation of long forms. Long forms differed from short forms in having no detectable amino acid pool, a characteristic that may be associated with excessive flagellar synthesis by developing long forms.
\end{abstract}

\section{INTRODUCTION}

In a previous paper (Jones \& Park, 1967) it was mentioned that the swarming of Proteus is always associated with a change in morphology from short to long forms. Reports in the literature are not in agreement about the morphological events which lead to the formation of swarming long forms of Proteus on agar media. KlienebergerNobel (1947) reported that the long forms arose from small uninucleate organisms formed by division of the short, relatively wide organisms present during the early stages of growth on nutrient agar. These small 'pre-swarmer' forms were not observed by Moltke (1927), Russ-Münzer (1935), Kvittingen (1949a, b), Hughes (1957) or Hoeniger (1964). Kvittingen (1949b) and Hughes (1957) reported a high mortality rate amongst long forms. Hughes considered that swarming long forms of Proteus were morphologically indistinguishable from long forms induced by penicillin; this view was not held by Hoeniger $(1964,1966)$. Reports also differ about the formation of long forms in nutrient broth cultures. Russ-Münzer (1935) and Klieneberger-Nobel (1947) did not detect long forms in nutrient broth cultures but Kvittingen (1949a) reported them to exist in large numbers after growth for $6 \mathrm{hr}$ at $37^{\circ}$.

Changes in morphology of micro-organisms have often been shown to be accompanied by alterations in the amount of specific cell components present or in their composition. Alterations in amino acid pools during formation of protoperithecia in Neurospora crassa (Barbesgaard \& Wagner, 1959), during multicellular differentiation of Dictyostelium discoideum (Wright \& Anderson, 1960) and during fruiting-body formation in Myxococcus xanthus (Dworkin, 1963) have been reported. SentheShanmuganathan \& Nickerson (1962) found differences in cell-wall composition as between triangular and ellipsoidal forms of Trigonopsis variabilis. Similarly, Bartnicki-

* Present address: Department of Microbiology, Yale University, New Haven, Connecticut, U.S.A. 
Garcia \& Nickerson (1962) showed that conversion of Mucor rouxii from filamentous to yeast-like growth resulted in a change in cell-wall composition.

Many agents which induce filament formation in Gram-negative bacteria interfere with some aspect of cell-wall formation (e.g. penicillin, Duguid, 1946; Rogers \& Mandelstam, 1962) or with synthesis of deoxyribonucleic acid (e.g. phenethylalcohol, Berrah \& Konetzka, 1962; nalidixic acid, Goss, Deitz \& Cook, 1964; high hydrostatic pressure, ZoBell \& Cobet, 1964).

The present paper describes morphological and cytological events during sequential stages of growth of Proteus on agar media and in liquid media and reports on a comparison of the chemical composition of cell fractions of short and long forms, which was done to see whether a chemical basis could be found for the differences between non-swarming and swarming organisms.

\section{METHODS}

Organisms. Proteus mirabilis NCDO 1881 was used for investigations on morphology and cytology of organisms. Proteus vulgaris NCDO 1882 was used for comparing the chemical composition of short and long forms. The maintenance of strains and the preparation of suspensions of organisms for inoculation were as described by Jones \& Park (1967).

Media. The media used were as described by Jones \& Park (1967).

Examination of cultures at sequential stages of growth. Twenty plates of nutrient agar dried for $1 \mathrm{hr}$ at $37^{\circ}$ were inoculated centrally with a drop (0.02 ml.) of a dense suspension of bacteria and incubated at $37^{\circ}$. One plate was withdrawn every $30 \mathrm{~min}$. and the colony immediately examined with a microscope with a $\times 40$ dry objective. After direct observation two impression preparations of segments taken from the centre to the edge of the colony were made on coverslips. One preparation was stained with dilute carbol fuchsin to show the gross morphology of the organisms, while the other was fixed in osmium tetroxide vapour for $3 \mathrm{~min}$. and stained to reveal nuclear material by the acid Giesma technique (Robinow, 1942). Because after each $30 \mathrm{~min}$. different plates were examined, different organisms were observed at each stage. The assumption was made that at any given time the cultures on all plates were at the same stage of development. From examination of the plates by eye it appeared that this assumption was valid, because swarms occurred at the same time on all plates used.

To follow the development of Proteus in liquid medium small volumes of nutrient broth in $\perp$-shaped vessels were inoculated and incubated in a water bath at $37^{\circ}$. For each experiment one vessel was left stationary while the other was shaken in an attempt to make the degree of aeration similar to that of surface cultures on nutrient agar. Smears prepared from each vessel every $30 \mathrm{~min}$. were stained with dilute carbol fuchsin and examined with the microscope.

Organisms from various cultures were examined for flagella after staining by the method of Rhodes (1958). Attempts were made to demonstrate cross walls in long forms of Proteus by the tannic acid + crystal violet method (Robinow, 1944) and the methods of Chance (1953) and Webb (1954). No cross walls were seen but, because the staining of walls of Gram-negative bacteria is often difficult, it was thought that the walls might be present but unstained. The plasmolysis method of Powell (1958) for detecting septation was therefore used to examine long forms from the moving edge of swarms. 
Collection of short and long forms for chemical analysis. Proteus vulgaris NCDO 1882 was used for comparing the chemical composition of short and long forms. This strain was chosen because it swarmed on nutrient agar at $30^{\circ}$ but not at $37^{\circ}$ and so could also be used to compare short forms grown at a temperature suitable for swarming with short forms grown at a temperature which was not suitable.

To obtain a yield of short forms a sample of bacterial suspension $(0.3 \mathrm{ml}$.) was spread over the surface of nutrient agar plates (diam. $9 \mathrm{~cm}$.) which had been dried for $1 \mathrm{hr}$ at $55^{\circ}$. After incubation for $4.5-5 \mathrm{hr}$ or $24 \mathrm{hr}$ at $30^{\circ}$ or $37^{\circ}$ organisms were harvested and washed twice in aqueous $\mathrm{NaCl}(0.5 \mathrm{M})$.

Long forms were collected from the swarming edge of colonies because this was the only way in which they could be obtained virtually free from short forms. In our hands the method used by Hoeniger (1965) to obtain long forms for electron microscopy gave a mixture of both forms. Nutrient agar plates $(14 \mathrm{~cm}$. diam.) were inoculated by placing a disc of filter paper $(5.3 \mathrm{~cm}$. diam.) soaked in a suspension of organisms at the centre of each plate. After incubation for $11 \mathrm{hr}$ at $30^{\circ}$ the second zone of each swarm was approaching the edges of the plates. The outer $5 \mathrm{~mm}$. of this moving zone consisted almost entirely of long forms and was harvested by removing the nutrient agar from inside this zone, so leaving the outer $5 \mathrm{~mm}$. of swarm and the uncovered agar surface intact on each plate. The swarming organisms were collected by washing them off the agar with $\mathrm{NaCl}(0.5 \mathrm{M})$. The washings from several plates were pooled and centrifuged and the sediment stored at $-20^{\circ}$. Long forms obtained over several weeks by many repetitions of this process were pooled, washed twice with aqueous $\mathrm{NaCl}(0.5 \mathrm{M})$ and kept at $-20^{\circ}$. The amount of long forms collected by this method was small (0.34 g. wet wt), but unwanted short forms were rare (Pl. 1, fig. 1).

Preparation of cell fractions. Because it was possible to collect only a small quantity of long forms, cell fractions were obtained in sequence from one batch of organisms. The sequence of Roberts et al. (1957) was used, but the methods for obtaining the fractions differed. The procedure is summarized in Fig. 1.

Analysis of cell fractions. Supernatant fluids which contained free amino acids were dried in vacuo over solid $\mathrm{NaOH}$ and the residues dissolved in small volumes of isopropanol + water $(10+90$, by vol.). Cell walls were hydrolysed in $6 \mathrm{~N}-\mathrm{HCl}$ in tightly capped $1 \mathrm{oz}$. McCartney bottles for $20 \mathrm{hr}$ at $105^{\circ}$. Hydrolysates were evaporated to dryness over a water bath, taken up in distilled water, again evaporated to dryness, and the amino acid residues dissolved in small volumes of isopropanol + water $(10+90$, by vol.). Free amino acids and cell-wall amino acids were identified by two-dimensional descending paper chromatography. Two solvent systems were used: (i) $n$-butanol + glacial acetic acid + water $(60+15+25$, by vol.), followed by ethanol + ammonia + water $(90+5+5$, by vol.), on Whatman no. 1 paper; (ii) $n$-butanol + methyl ethyl ketone +ammonia (sp.gr. $0 \cdot 880)+$ water $(50+30+10+10$, by vol.; Wolfe, 1957) followed by $n$-butanol + glacial acetic acid + water $(60+15+25$, by vol.) on Whatman no. 4 paper. Positions of compounds were determined by dipping the papers in a solution of ninhydrin $(0.5 \%, \mathrm{w} / \mathrm{v})$ in acetone + water $(95+5$, by vol.). Amino sugars were detected by the silver nitrate reagent for sugars (Trevelyan, Procter \& Harrison, 1950) and by the Elson \& Morgan reagent (Smith, 1960).

DNA content was estimated by the diphenylamine method of Burton (1956) with herring DNA as standard, and RNA by the orcinol method of Ceriotti (1955) with D-ribose as standard. 


\section{Washed organisms \\ $\downarrow$}

Acetic acid $(10 \%, \mathrm{v} / \mathrm{v})$ in water for $2 \mathrm{hr}$ at room

temperature.

Centrifuge, remove supernatant fluid (Mattick,

Cheeseman, Berridge \& Bottazzi, 1956)

Precipitate $\longrightarrow \begin{gathered}\text { Keep supernatant fluid, which con- } \\ \text { tains amino acid pools }\end{gathered}$

Ethanol + water $(75+25$, by vol.) at $\mathrm{pH} 2 \cdot 5-3 \cdot 0$ for

$30 \mathrm{~min}$. at $45^{\circ}$.

Centrifuge, remove supernatant fluid.

Ethanol + water + ether $(37 \cdot 5+12 \cdot 5+50$, by vol. $)$

for $15 \mathrm{~min}$, at $45^{\circ}$.

Centrifuge, remove supernatant fluid



$0.5 \mathrm{~N}$-perchloric acid solution for $20 \mathrm{~min}$. at $70^{\circ}$.

Centrifuge, remove supernatant fluid.

Repeat extraction, centrifuge, remove supernatant

fluid (Ogur \& Rosen, 1950)

$\longrightarrow$ Precipitate $\longrightarrow$ Keep supernatant fluids

Ethanol + water $(75+25$, by vol.).

Centrifuge, remove supernatant fluid.

Ether. Centrifuge, remove supernatant fluid

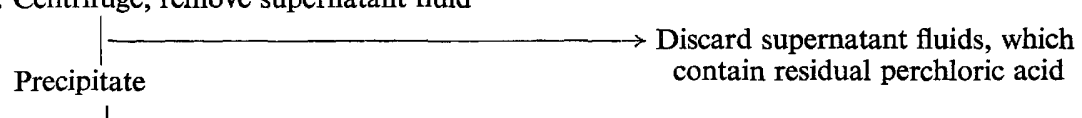

Trypsin (B.D.H., Poole; 0.005\%, w/v) in water at

pH 8.0 for $3 \mathrm{hr}$ at $37^{\circ}$.

Centrifuge, remove supernatant fluid.

Repeat digestion, centrifuge, remove supernatant fluid

(Park \& Hancock, 1960)



Wash three times in distilled water to remove residual

trypsin solution

$\downarrow$

Cell walls from which much of the sugar content would have been removed during the fractionation procedure

Fig. 1. Summary of the procedure for separation of cell fractions.

\section{RESULTS}

Morphology and cytology of organisms at sequential stages of growth

The stages of growth on nutrient agar before swarming were: (1) enlargement of the small coccoid organisms of the inocula to typical short forms each with 2-4 nuclear units; (2) multiplication of these short forms; (3) elongation of short forms at the edge of the colony after incubation for $3-3 \cdot 5 \mathrm{hr}$ to give long forms which 
moved around each other. At stage 3 swarming then started and was visible to the unaided eye when the culture had been incubated for a total of $4 \mathrm{hr}$. The long forms moved across the nutrient agar surface en masse or occasionally in groups detached from the advancing edge. This observation agrees with that described by Hoeniger (1964). The development of a mass of small uninucleate 'pre-swarmer' forms as reported by Klieneberger-Nobel (1947) was not observed.

The number of nuclear units per organism depended on the length of the organism. Long forms were up to $70 \mu$ long and had up to 46 nuclear units. The acid Giemsa technique thus indicated that DNA synthesis had not been inhibited (Pl. 1, figs. 2, 3). Cell-wall stains and plasmolysis experiments indicated that long forms had no cross walls; none were seen after staining for cell walls and on plasmolysis the protoplasm of each long form showed as only one unit. It was concluded that cell division was prevented at some stage before the formation of cross walls. Hoeniger (1966) did not see cross walls in Proteus long forms but did demonstrate separate units of protoplasm by plasmolysis followed by fixation and staining with thionin. Flagella appeared on the short forms after incubation on nutrient agar for $3 \mathrm{hr}$. The long forms which subsequently developed at $30^{\circ}$ usually had more flagella per unit length of organism than did short forms, but detachment of flagella from organisms during the staining procedure made comparisons of numbers difficult. Hoeniger (1965), who used electron microscopy for observing the flagella of Proteus organisms, showed that long forms had more and longer flagella per unit length of organism than did short forms.

At no time during incubation for $10 \mathrm{hr}$, after $24 \mathrm{hr}$ or after $48 \mathrm{hr}$ were long forms seen in samples from cultures in shaken nutrient broth, in static nutrient broth, in static liquid minimal medium plus Casamino acids $(1 \%, \mathrm{w} / \mathrm{v})$ or in static liquid minimal medium plus M/16 L-glutamic acid (Jones \& Park, 1967); all these media, when solidified with agar, supported swarming. Long forms in liquid media have been reported by Kvittingen (1949a).

\section{Chemical composition of cell fractions of short and long forms}

Free amino acids were not found in the acetic acid extract from long forms. This indicated either that free amino acids were not present in long forms or that they had been lost during the collection procedure. Loss might have occurred because the cell envelope of long forms was naturally more permeable than was that of short forms or because it was made permeable by the freezing and thawing associated with the collection procedure. The free amino acids found in short forms are shown in Table 1. Preparations from short forms grown for $24 \mathrm{hr}$ were added to chromatograms at five times the concentration of those from organisms grown for $4.5-5 \mathrm{hr}$ because of the weak reaction with ninhydrin of the acetic acid extracts from organisms grown for $24 \mathrm{hr}$. There was no qualitative difference in the free amino acids obtained from cultures grown for the same time at $30^{\circ}$ or $37^{\circ}$, but there was more amino acid material in organisms grown for $4.5 \mathrm{hr}$ than in organisms grown for $24 \mathrm{hr}$. A larger variety of free amino acids is typical of young cultures of bacteria (Berridge, Cheeseman, Mattick \& Bottazzi, 1957; Gregory \& Mabbitt, 1957). The occurrence of $\beta$-alanine and lysine as the major free amino acids from $24 \mathrm{hr}$ cultures is unusual. $\beta$-Alanine is found as a major component in fungi (Holden, 1962) but so far as we are aware in bacteria it has been found only in Corynebacterium diphtheriae (Work, 1949). The 
presence of the amino sugar, which was probably glucosamine, is interesting since we have found no other reports of amino sugars in amino acid pools from bacteria or fungi. However, perhaps some of the 'unknown' spots often reported on chromatograms of amino acid pools are amino sugars.

\title{
Table 1. Free amino acids obtained from short forms of Proteus vulgaris NCDO1882 grown on nutrient agar
}

\begin{abstract}
Increasing number of + signs indicates increasing amounts of amino acid determined visually by intensity of colour formed with ninhydrin. \pm indicates colour just detectable. Because of differences in spot sizes between different amino acids on the chromatograms comparisons of concentrations made across the table are more valid than those made vertically. Amino acid pools from organisms grown for $24 \mathrm{hr}$ were added to chromatograms at five times the concentration of amino acid pools from organisms grown for $4.5 \mathrm{hr}$.
\end{abstract}

$\begin{array}{cccc}\begin{array}{c}\text { Short forms } \\ \text { collected after } \\ \text { growth for }\end{array} & \begin{array}{c}\text { Short forms } \\ \text { collected after } \\ \text { growth for }\end{array} & \begin{array}{c}\text { Short forms } \\ \text { collected after } \\ \text { growth for }\end{array} & \begin{array}{c}\text { Short forms } \\ \text { collected after } \\ \text { growth for }\end{array} \\ \begin{array}{c}4.5 \mathrm{hr} \text { at } 37^{\circ} \\ 4.5 \mathrm{hr} \text { at } 30^{\circ}\end{array} & 24 \mathrm{hr} \text { at } 37^{\circ} & 24 \mathrm{hr} \text { at } 30^{\circ}\end{array}$

Alanine
$\beta$-alanine
Arginine
Aspartic acid
Citrulline or glutamine
Diaminopimelic acid
Glutamic acid
Glycine
Lysine
Leucine or isoleucine
Methionine
Phenylalanine
Proline
Serine
Threonine
Tyrosine
Amino sugar

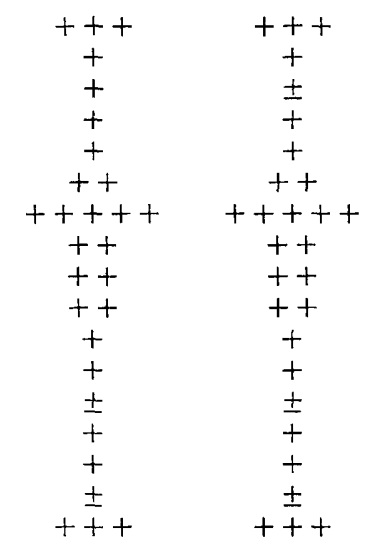

$$
\begin{array}{cc}
- & - \\
++ & ++++ \\
- & - \\
+ & + \\
\overline{ \pm} & \pm \\
\pm & \pm \\
\pm & \overline{+} \\
++ & ++ \\
- & - \\
- & - \\
- & - \\
- & - \\
- & - \\
- & +++ \\
++ & ++
\end{array}
$$

The results of nucleic acid estimations expressed as mg./g. wet wt organism, and as DNA/RNA ratios are given in Table 2. Expressing DNA as a fraction of RNA overcomes inaccuracies due to loss of organisms in the extraction procedures. There was not sufficient material from long forms for the results to be expressed in terms of wet wt organisms. Short forms from colonies grown for $4.5 \mathrm{hr}$ and long forms gave the same DNA/RNA ratio. This similar ratio confirms the cytological finding that the formation of the long forms was not a result of inhibition of DNA synthesis. Short forms from colonies grown for $24 \mathrm{hr}$ had a higher DNA/RNA ratio due to a decrease in the amount of RNA. This result is consistent with those reported for other washed resting bacteria (Mitchell \& Moyle, 1951; Wade \& Morgan, 1957).

The amino acids found in cell-wall hydrolysates (alanine, arginine, aspartic acid, diaminopimelic acid, glutamic acid, glycine, histidine, lysine, leucine and/or isoleucine, methionine, phenylalanine, proline, serine, threonine, tyrosine, valine, a trace of citrulline, an amino sugar) were, with one exception, the same as found by Kandler, Hund \& Zehender (1958) in cell walls of Proteus vulgaris; however, Kandler et al. did not find arginine. We found no qualitative difference between the amino acid content of cell walls from short and long forms. Insufficient long-form material was available for a reliable quantitative estimation to be made. 


\section{DISCUSSION}

Swarming long forms of Proteus were produced on nutrient agar, at the edge of colonies, but not in nutrient broth. The relationship between growth rate and swarming (Jones \& Park, 1967) suggests that long forms occur only at the edge of a colony because it is there that nutrients are most readily available and organisms can grow fastest. It is not known why long forms occur on agar-solidified media but not in either static or agitated liquid media. It seems unlikely that the difference is due to the chemical nature of agar or to impurities in it. Hauser (1885) found long forms on

\section{Table 2. Estimations of DNA and RNA in short and long forms of} Proteus vulgaris NCDO 1882 grown on nutrient agar

$\begin{array}{cccc} & \begin{array}{c}\text { DNA } \\ \text { expressed as } \\ \text { mg./g. wet wt } \\ \text { organism }\end{array} & \begin{array}{c}\text { RNA } \\ \text { expressed as mg. } \\ \text { purine-bound } \\ \text { ribose/g. wet wt } \\ \text { organism }\end{array} & \begin{array}{c}\text { DNA/RNA } \\ \text { ratio, i.e. mg. } \\ \text { DNA per 1 mg. } \\ \text { of purine-bound } \\ \text { ribose of RNA }\end{array} \\ \begin{array}{c}\text { Short forms collected after growth } \\ \text { for } 4.5 \mathrm{hr} \text { at } 37^{\circ}\end{array} & 6.6 & 11.6 & 0.59 \\ \begin{array}{c}\text { Short forms collected after growth } \\ \text { for } 4.5 \mathrm{hr} \text { at } 30^{\circ}\end{array} & 8.1 & 15.6 & 0.54 \\ \begin{array}{c}\text { Short forms collected after growth } \\ \text { for } 24 \mathrm{hr} \text { at } 37^{\circ}\end{array} & 8.0 & 1.3 & 5.94 \\ \begin{array}{c}\text { Short forms collected after growth } \\ \text { for } 24 \mathrm{hr} \text { at } 30^{\circ}\end{array} & 9.9 & 4.7 & 2.06 \\ \begin{array}{c}\text { Long forms collected from second } \\ \text { zone of swarm at } 30^{\circ}\end{array} & * & * & 0.64 \\ * \text { Insufficient material available for accurate weighing. } & \end{array}$

media solidified with gelatin and Jones (1966) found long forms on media solidified with either New Zealand agar (Davis) or purified agar (Difco). Jones (1966) also found that swarming occurred on agar media to which $0.5 \%(\mathrm{w} / \mathrm{v})$ charcoal or starch had been added to adsorb impurities such as fatty acids (Pollock, 1947), but Smith \& Alwen (1966), who used $1 \%$ (w/v) charcoal did inhibit swarming of Proteus. However, it seems that the important effect of agar so far as the swarming of Proteus is concerned is to change the physical state of the medium.

Thus long forms appear to develop because cell division is inhibited at some stage before the formation of cross walls, and not because synthesis of DNA is inhibited. Long forms differ from short forms harvested from young cultures on nutrient agar; the long forms have more flagella per unit length of organism and no free amino acid pool. The formation of long forms with many flagella in a Proteus culture on a solid medium may be considered as an event arising from a 'discontinuous biochemical process' similar to that postulated by Quadling \& Stocker (1957) to explain the occurrence of rare motile bacteria in cultures of non-motile salmonellae. We suggest that the formation of long forms and the formation of many flagella are not independent processes but that one is dependent on the other. At an appropriate growth rate (Jones \& Park, 1967) flagella synthesis or perhaps the synthesis of flagellasynthesizing sites becomes uncontrolled, and this results in a decrease in the amino acid pool, so that cell division is prevented by a shortage of amino acids or some other intermediate needed for the cell-division mechanism. The resultant long, heavily 
flagellate forms are able to move over the surface and so spread to hitherto unpopulated areas of agar where synthesis of flagella ceases, and division is resumed to give short forms once more.

\section{REFERENCES}

BARBesGaARD, P. Ø. \& WAGNER, S. (1959). Further studies on the biochemical basis of protoperithecia formation in Neurospora crassa. Hereditas 45, 564.

BarTNICKI-GARCIA, S. \& NICKerson, W. J. (1962). Isolation, composition and structure of cell walls of filamentous and yeast-like forms of Mucor rouxii. Biochim. biophys. Acta 58, 102.

BERRAH, G. \& KonETZKA, W. A. (1962). Selective and reversible inhibition of the synthesis of bacterial deoxyribonucleic acid by phenethyl alcohol. J. Bact. 83, 738.

Berridge, N. J., Cheeseman, G. C., Mattick, A. T. R. \& Bottazzi, V. (1957). The differentiation of bacterial species by paper chromatography. II. Lactobacilli and Streptococci; the effect of age of culture. J. appl. Bact. 20, 195.

BurTON, K. (1956). A study of the conditions and mechanism of the diphenylamine reaction for the colorimetric estimation of deoxyribonucleic acid. Biochem. J. 62, 315 .

CERIOTTI, G. (1955). Determination of nucleic acids in animal tissues. J. biol. Chem. 214, 59.

Chance, H. L. (1953). A bacterial cell wall stain. Stain Technol. 28. 205.

DugUID, J. P. (1946). The sensitivity of bacteria to the action of pencillin. Edinb. med. J. 53, 401.

Dworkin, M. (1963). Nutritional regulation of morphogenesis in Myxococcus xanthus. J. Bact. 86, 67.

Goss, W. A., DeITZ, W. H. \& CooK, T. M. (1964). Mechanism of action of nalidixic acid on Escherichia coli. J. Bact. 88, 1112.

GREGORY, M. \& MABBITT, L. A. (1957). The differentiation of bacterial species by paper chromatography. IV. An examination of the micrococci, with special reference to the influence on the chromatograms of medium and age of culture. J. appl. Bact. 20, 218.

HAUSER, G. (1885). Über Fäulnissbacterien und deren Beziehungen zur Septicamie. Leipzig: F. G. W. Vogel.

HoENIGER, J. F. M. (1964). Cellular changes accompanying the swarming of Proteus mirabilis. I. Observations of living cultures. Can. J. Microbiol. 10, 1.

HoEniger, J. F. M. (1965). Development of flagella by Proteus mirabilis. J. gen. Microbiol. 40, 29.

HoENIGER, J. F. M. (1966). Cellular changes accompanying the swarming of Proteus mirabilis. II. Observations of stained organisms. Can. J. Microbiol. 12, 113.

Holden, J. T. (1962). The composition of microbial amino acid pools. In Amino Acid Pools. Ed. by J. T. Holden, p. 73. New York: Elsevier.

Hughes, W. H. (1957). A reconsideration of the swarming of Proteus vulgaris. J. gen. Microbiol. $17,49$.

JoNEs, H. E. (1966). The Swarming Phenomenon of the Bacterial Genus Proteus. Ph.D. thesis, University of Reading.

JONES, H.E. \& PARK, R. W. A. (1967). The influence of medium composition on the growth and swarming of Proteus. J. gen. Microbiol. 47, 369.

KANDLER, O., HUND, A. \& ZEHENDER, C. (1958). Cell wall composition in bacteria and L-forms of Proteus vulgaris. Nature, Lond. 181, 572.

KLIENEBERGER-NOBEL, E. (1947). Morphological appearances of various stages in B. proteus and E. coli. J. Hyg., Camb. 45, 410.

Kvittingen, J. (1949a). Studies of the life-cycle of Proteus Hauser, Part I. Acta path. microbiol. scand. 26, 24.

Kvittingen, J. (1949b). Studies of the life-cycle of Proteus Hauser, Part II. Acta path. microbiol. scand. 26, 855 .

Mattick, A. T. R., Cheeseman, G. C., Berridge, N. J. \& Bottazzi, V. (1956.) The differentiation of species of lactobacilli and streptococci by means of paper partition chromatography. J. appl. Bact. 19, 310.

MITCHELl, P. \& MOYLE, J. (1951). Relationships between cell growth, surface properties and nucleic acid production in normal and penicillin-treated Micrococcus pyogenes. J. gen. Microbiol. 5, 421.

MOLTKE, O. (1927). Contributions to the characterisation and systematic classification of Bact. proteus vulgaris (Hauser). Copenhagen: Leven and Munksgaard.

OGuR, M. \& Rosen, C. (1950). The nucleic acids of plant tissues. I. The extraction and estimation of desoxypentose nucleic acid and pentose nucleic acid. Archs Biochem. 23, 262.

PARK, J. T. \& HANCOCK, R. (1960). A fractionation procedure for studies of the synthesis of cell-wall mucopeptide and of other polymers in cells of Staphylococcus aureus. J. gen. Microbiol. 22, 249.

PolLOCK, M. R. (1947). The growth of H. pertussis on media without blood. Br. J. exp. Path. 28, 295. 
Journal of General Microbiology, Vol. 47, No. 3

Plate 1
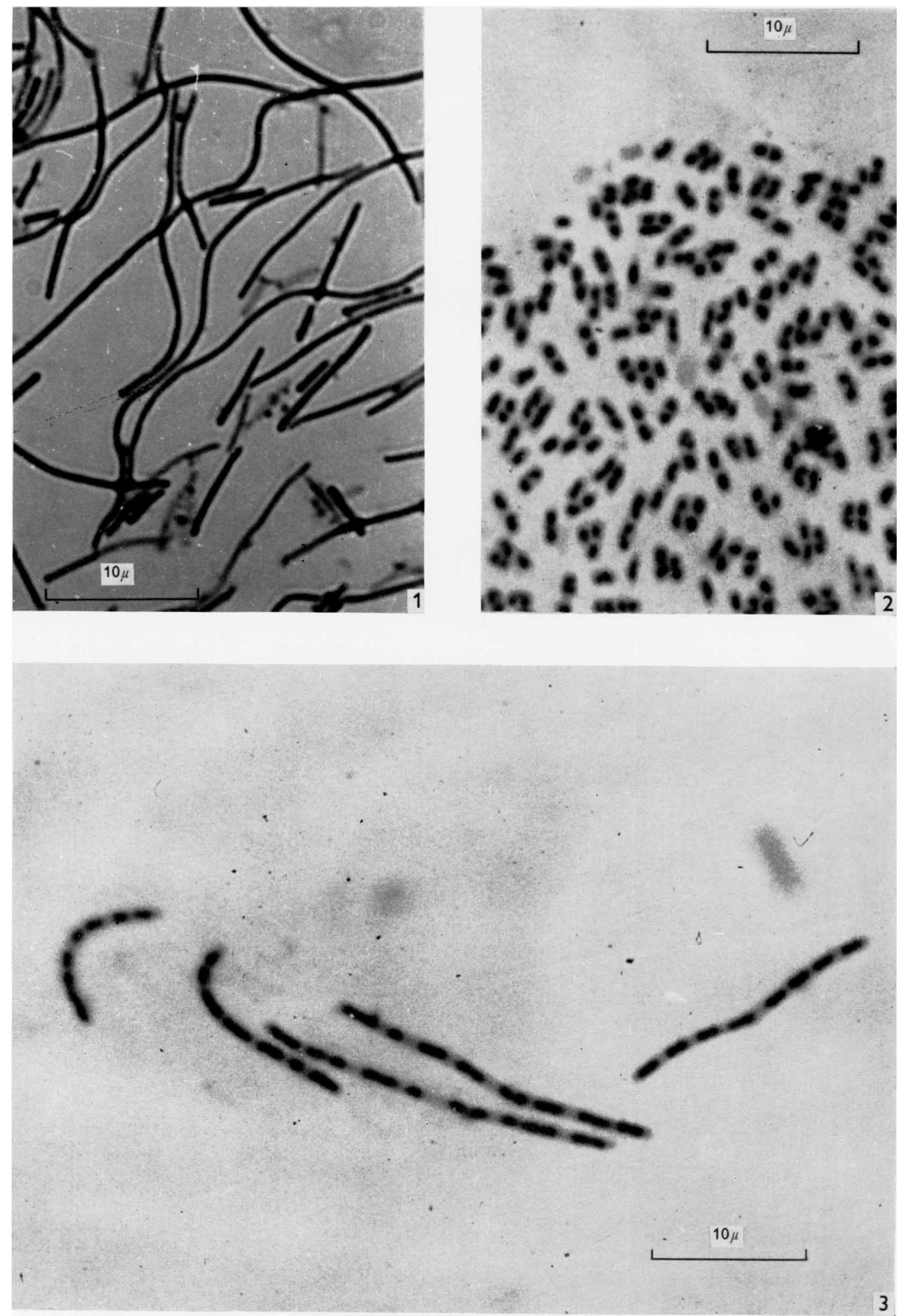
Powell, E. O. (1958). An outline of the pattern of bacterial generation times. J. gen. Microbiol. 18, 382 .

QuAdling, C. \& Stocker, B. A. D. (1957). The occurrence of rare motile bacteria in some non-motile Salmonella strains. J. gen. Microbiol. 17, 424.

RHoDes, M. E. (1958). The cytology of Pseudomonas spp. as revealed by a silver-plating staining method. J. gen. Microbiol. 18, 639.

Roberts, R. B., Abelson, P. H., Cowie, D. B., Bolton, E. T. \& Britten, R. J. (1957). Studies of biosynthesis in Escherichia coli. 2nd printing. Publs Carnegie Instn no. 607.

RobINow, C. F. (1942). The structure of the nuclear apparatus of bacteria. Proc. R. Soc. B 130, 299.

Robinow, C. F. (1944). Cytological observations on Bact. coli, Proteus vulgaris and various aerobic spore-forming bacteria with special reference to the nuclear structures. J. Hyg., Camb. 43, 413.

RoGERS, H. J. \& MANDELSTAM, J. (1962). Inhibition of cell-wall-mucopeptide formation in Escherichia coli by benzylpenicillin and 6 -[D(-)- $\alpha$-aminophenylacetamido] pencillanic acid (Ampicillin). Biochem. J. 84, 299.

Russ-Münzer, A. (1935). Das Schwärmphänomen bei Bacillus proteus. Zentbl. Bakt. ParasitKde (I. Abt. Orig.) 133, 214.

SentheShanmuganathan, S. \& Nickerson, W. J. (1962). Composition of cells and cell walls of triangular and ellipsoidal forms of Trigonopsis variabilis. J. gen. Microbiol. 27, 451.

Smith, D. G. \& ALwen, J. (1966). Effect of activated charcoal on the swarming of Proteus. Nature, Lond. 212, 941.

SmITH, I. (1960). Chromatographic and Electrophoretic Techniques. Volume 1. Chromatography. 2nd ed. London: Heinemann.

Trevelyan, W. E., Procter, D. P. \& Harrison, J. S. (1950). Detection of sugars on paper chromatograms. Nature, Lond. 166, 444.

WADE, H. E. \& MORGAN, D. M. (1957). The nature of the fluctuating ribonucleic acid in Escherichia coli. Biochem. J. 65, 321.

WeBB, R. B. (1954). A useful bacterial cell wall stain. J. Bact. 67, 252.

WolfE, M.(1957). The quantitative determination of amino acids by paper chromatography. A solvent to replace phenol. Biochim. biophys. Acta 23, 186.

Work, E. (1949). Chromatographic investigations of amino acids from micro-organisms. 1. The amino acids of Corynebacterium diphtheriae. Biochim. biophys. Acta 3, 400 .

Wright, B. E. \& ANDERson, M. L. (1960). Protein and amino acid turnover during differentiation in the slime mould. I. Utilisation of endogenous amino acids and proteins. Biochim. biophys. Acta 43, 62 .

ZoBell, C. E. \& CoBET, A. B. (1964). Filament formation by Escherichia coli at increased hydrostatic pressures. J. Bact. 87, 710 .

\section{EXPLANATION OF PLATE}

Fig. 1. A representative sample of the harvest of organisms from the swarming edge of cultures of Proteus vulgaris NCDO1882; stained with dil. carbol for $30 \mathrm{sec}$. The harvest consisted almost entirely of long forms. Scale on photograph.

Figs. 2, 3. Impression preparations of Proteus mirabilis NCDO1881 grown on nutrient agar at $37^{\circ}$ and stained by the acid Giemsa method to show nuclear material (dark areas). Fig. 2. Organisms from the edge of a culture after incubation for $2.5 \mathrm{hr}$ : scale on photograph. Fig. 3. Organisms from the swarming edge of a culture after incubation for $4 \mathrm{hr}$ : scale on photograph. 